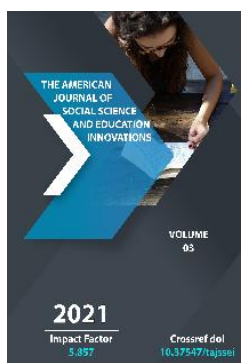

Copyright: Original content from this work may be used under the terms of the creative commons attributes 4.0 licence.

\section{On The Issue Of The Formation Of The Rural Settlement Of Sogd}

\author{
H.O. Rakhmonov \\ Junior Researcher National Archaeological Center Of The Academy Of Sciences Of The \\ Republic Of Uzbekistan \\ N.A. Makhkamova \\ Junior Researcher National Archaeological Center Of The Academy Of Sciences Of The \\ Republic Of Uzbekistan
}

\title{
ABSTRACT
}

This article describes the influence of nomadic pastoral peoples on the emergence of rural areas in Sughd. The article provides a brief analysis of pottery samples found in tombs in Sughd and the impact of steppe culture on pottery.

\section{KEYWORDS}

Sughd, pottery, culture, pottery.

\section{INTRODUCTION}

The household of population of Central Asia

nomadic herders. In the Sogd region there were favorable conditions has been formed from ancient times by natural geographical features. Due to the first division of labor that took place during the Bronze Age, the population of Central Asia was divided into groups of settled and

for the formation and development of nomadic animal husbandry along with the oasis. That is why the ancient inhabitants grazed their livestock along the Central Asian 
steppes and deserts, river basins and mountain slopes. At the same time, some of them have traditionally farmed, some have settled in favorable farming areas and were engaged with farming and crafts. The advent of nomadic herders played an important role in the approchement and merging of cultures of the two farms. Thus, from the Bronze Age, from the Zarafshan to the Amu Darya and to the south, the Turkish tribes became Turan indigenous inhabitants.

The archeological monuments of Sogd oasis and its borders reflected the formation of historical, geographical, economic, cultural and ethnic features here. The Zarafshan oasis and its adjacent steppes, deserts and mountain landscapes, with its geographical features, have provided the development not only the sedentary farming, but also nomadic cattle breeding.

Obelchenko researched numerous burial sites of herders in Zarafshan oasis and attributed them to three groups chronologically, arguing that the influence of steppe culture on Sogd was greatly enhanced during antiquity - early $B C$, investments in the Aral Sea, Lower Syrdarya and Kyzylkum. However, in the material culture samples of burial mounds in the middle part of Zarafshan such as Sazaghan, Mirankul and Akjartepa shows the influence of yuezhi, usun and the Huns who moved through the Middle Syrdarya region. The ceramic dishes studied in them have a close resemblance for preparing and shape to the ceramics of burial ground which were found from Shirinsay, Gulbo in Ustrushana, Karabulak, Jangail, Isfara which related to Kugay-Karabulak culture in the Ferghana Valley. This indicates that the settlers came to Sogd also from along the Middle Syrdarya and through Ustrushana. As a result of this migration, the influence of steppe culture spreads to the towns of the indigenous peoples of Central Sogd. It is especially noticeable in such monuments as Kofir-Kala, Tali-Barzu, Akjartepa.

\section{THE MAIN FINDINGS AND RESULTS}

In the Sogd materials local traditions were in a dominant position, the influence of steppe culture is evident on ceramic vessels. For example, jugs and mugs are without the tap, but the handle is made in animal form. Ceramic containers contain large and small size bowls, waterpots and plates. In general, the technology, shape, and surface design of ceramic dishes, studied in Sogd, are characteristic of breeding pottery (Obelchenko 1969. p. 90).

Historical sources indicate that some ancient and early medieval nomad groups (turkish languages the Huns, the Usuns, the Chionites, the Kidarites, the Eftalites, the Turks, etc.) did not move south, they remained in the oasis and favorable places for livestock and they kept these areas as their own wintering. They are looking for grassland pastures, mainly settled down in the foothills, mountains, rivers and stream valleys, in areas not yet mastered by local herds and livestock. They continued the tradition of specialized farming and engaged not only in nomadic livestock but also in farming.

In the Sogd rural areas in the V-VI centuries there was a change in the quality of raw materials made in accordance with local traditions and the nomadic features began to appear. This can be seen in all areas, from household goods to funerals. This is especially true in pottery. In Sogd at the beginning of the Christian era, radical changes took place in ceramics, now they are completely hand- 
made, ceramic dishes bottom became flat. Most of the dishes are bright red and white engobed, with brown or black streaks. They are jugs, pots, tall jars and small jars, with a narrow part of their necks, slightly collared rims, sometimes with a cross or double triangle or cross stamped on their bodies. Wavy and straight lines were used to give them a pattern.

The neck of jugs are longer, sometimes the upper part of the handle is made of animalshaped. On the opposite side of the handle of jug is attached tap. The surface of such jugs is decorated in black, sometimes colored ornament described wavy-shaped . Some jars made with wide mouths and flat bottoms with small double handles on their bodies. The upper part is decorated like a jug.

There are plenty of ceramic cauldrons in Sogd, not only in the monuments of the livestock, but also in the complex of rural and urban pottery. They are with double-ear, spherical, coarseware, black and burnt. Their flaming parts are brownish, reddish brown. The cauldrons are made of loess soil clay, and to be refractory they added to clay crushed limestone and shells of molusks.

Among the ceramics there many mugs with the zoomorphic handle. Their body part is spherical, above the corpse a little bit bent out or raised upright. Among the mugs cylindrical forms are also found. The upper part of the handle of mugs end with the animal figure. Another common type of ceramic vessels are (pottery) bowl which below the neck part is cone-shaped, with wide mouths, plein and narrow bottom, neck part separated from conical body. Sometimes, between them there double handle bowls.
According to M. Pardaev who studied and analyzed the ceramic vessels of Ustrushana "There is some complexity in the scientific analyzes of the samples of ceramics found in the archeological monuments of North-west Usturshana and to do periodization by them. The reason for this complexity is that the region has a high influence of interaction and mixing, as it is a crossroads for settlement and nomadic, steppe cultures " (Pardaev, 1998, p. 58). This feature is also characteristic of Sogdian ceramics, where ceramic bottles complement each other.

Another important characteristic mark of the early medieval Sogd is that in this period the handle of pots and mugs were made in real animalistic form. Appeared jugs with a wavy line ornamented on the outside. For the first time appeared plate shape dishes or finger printed floral ceramic tableware (tablecloth) (Pardaev, 1998, p. 59). Such kind of floral dishes found in the Usturshana monuments are also characteristic of the early medieval ceramics of Sogd, ancient Ferghana, and Movarounnahr in general (Filanovich, 1983, p. 61). These effects are also evident in the architecture. At the same time, as the population moves across the oasis, monumental defensive structures appear as an innovation, radical qualitative changes occur in the structure of the archaeological complex, and amplified cfming of the herder Turkish ethnic groups among the local population.

\section{CONCLUSION}

Thus, in antiquity and early medieval ages between the nomadic and local (herder and settled) populations the exchange and trade relations have strengthened. Qualitative changes in material culture are evidence of 
this. The activities of the villagers we studied were also related to these processes. Numerous buildings, such as palaces, castles, fortresses have been built in agricultural oasises. Various handicrafts have been developed, commercy prospered and irrigation facilities have been built. Many new cities have been built around the old cities. Large villages and towns were inhabited by influential tribal leaders, tribal or community elders, wealthy families and partially craftsmen. These buildings are mostly built of adobe and mud-brick on a high platform. However, most of the population was scattered and lived in small villages, in basements, in houses and yards, and in semiarid and nomadic households. During this period the complementary culture of the settled and nomadic population was formed in the oasis villages.

\section{REFERENCES}

1. Shoniyozov K.Sh. Gang state and gangsters. Tashkent, 1990.

2. Khojaev A. Information on the history of Fergana. Fergana, 2013.

3. Isakov A., Potemkina T.M. Burial ground of tribes of the Bronze Age in Tajikistan. // CA issue. 1 - Moscow, 1989.

4. Obelchenko OV The culture of ancient Sogd. M, 1991.

5. Obelchenko OV Akzhartepe burial ground // IMKU, vol. 3. Tashkent, 1962.

6. Obelchenko OV Mirankul burial // IMKU vol. 8. - Tashkent, 1969.

7. Pardaev MH Pottery of Jizzakh oasis of IV-VI centuries // IMKU вып. 29. Samarkand, 1998.
8. Filanovich M.I. The origin and development of the city and urban culture. Tashkent, 1983. 